\title{
An expedient solvent-free synthesis of (Z)-2-alkylidene-4-oxothiazolidine derivatives under microwave irradiation
}

\author{
Rade Marković, ${ }^{\text {a,b }}$ Miodrag M. Pergal, ${ }^{\text {a }}$ Marija Baranac, ${ }^{a}$ Dragomir Stanisavljev, ${ }^{c}$ and \\ Milovan Stojanovićb \\ ${ }^{a}$ Faculty of Chemistry, University of Belgrade, Studentski trg 16 P. O. Box 158, 11001 Belgrade, \\ Serbia and Montenegro; ${ }^{b}$ Center for Chemistry ICTM, P. O. Box 473, 11000 Belgrade, Serbia and \\ Montenegro; ${ }^{c}$ Faculty of Physical Chemistry, University of Belgrade, Studentski trg 16, 11001 \\ Belgrade, Serbia and Montenegro \\ E-mail: markovic@helix.chem.bg.ac.yu
}

(received 10 Nov 05; accepted 20 Dec 05; published on the web 3 Jan 06)

\begin{abstract}
A new and efficient microwave-assisted synthesis of (Z)-2-alkylidene-4-oxothiazolidine derivatives 4 under solvent-free conditions and without solid support, is described. In comparison to conventional technique, experimental evidence reveals the benefits of the MW-promoted synthesis of functionalized 4-oxothiazolidine derivatives $\mathbf{4}$ in terms of simple workup, efficiency and safe reproducibility. The method, as environmentally cleaner, was shown to be potentially applicable to similar chemical processes, such as the preparation of not easily obtainable 4-oxo-1,3-thiazinan-2ylidene derivative 6.
\end{abstract}

Keywords: 4-Oxothiazolidine, $\beta$-enamines, microwave irradiation, solvent-free synthesis

\section{Introduction}

The advantages of numerous microwave (MW)-induced reactions over conventional reactions, and their utility in organic synthesis, have been fully recognized in the last two decades. ${ }^{1}$ Well-known applications of the MW methodology involve the effective syntheses and functionalization of various and structurally diverse heterocyclic compounds. ${ }^{2}$ Among them, a few examples of MWassisted syntheses of a series of 2-substituted 4-thiazolidinones, based exclusively on the condensation-cyclization sequence employing a three-component reaction mixture of a substituted acyclic or aromatic primary amine or diamine, aldehyde and mercaptoacetic acid, have been described. ${ }^{3}$ Other common methods to construct a 4-oxothiazolidine skeleton, for example, (i) by treatment of $\alpha$-haloalkanoic acids and their derivatives, ${ }^{4}$ or dimethyl acetylenedicarboxylate ${ }^{5}$ with substituted thioureas, (ii) from ammonium dithiocarbamates and glycidic esters, ${ }^{6}$ or (iii) by one-pot 
cyclization of arylacetonitriles with $N$-phenylisothiocyanate and ethyl 2-chloro-2-oxoacetate, ${ }^{7}$ are limited to classical liquid-phase synthesis.

In a continuation of our studies on the chemistry of heterocyclic enaminones and enaminonitriles, containing the 4-oxothiazolidine moiety ${ }^{8}$ which is of broad synthetic and biological relevance, ${ }^{4,9,10}$ we wish to report the first dry-media microwave synthesis of $\beta$-enamino-type $(Z)-4$ oxothiazolidine derivatives $4^{11,12}$ (Scheme 1), from activated nitriles $\mathbf{1}$ and $\alpha$-mercaptoesters 2. Literature search indicates that only two examples of microwave synthesis of the heterocyclic compounds possessing the exocyclic $\mathrm{C}=\mathrm{C}$ bond, i.e., 4-alkylidene- $1 H$-imidazol-5(4H)-ones ${ }^{13}$ and 2phenyl-4-arylidene-5(4H)-oxazolones, ${ }^{2}$ have been reported so far.

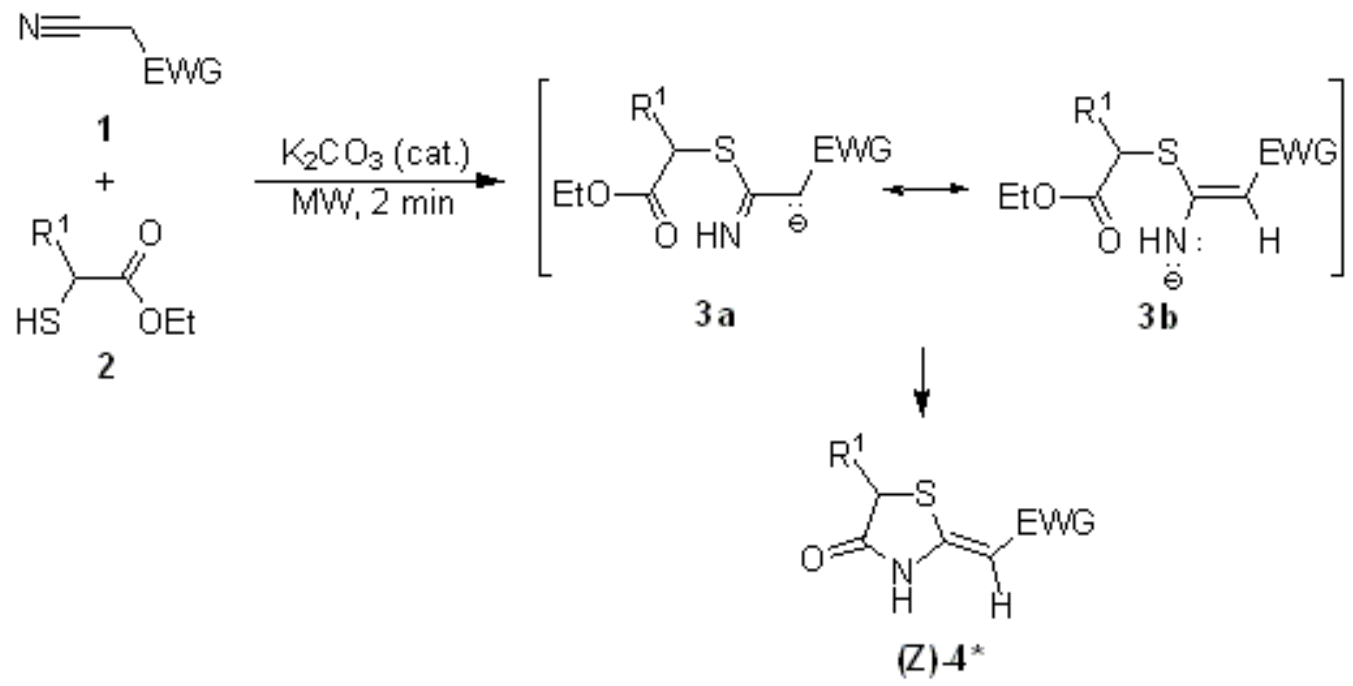

$$
\begin{aligned}
& \mathrm{EWG}=\mathrm{COPh}, \mathrm{CO}_{2} \mathrm{Et}, \mathrm{CN}, \mathrm{CONHPh}, \mathrm{CONH}\left(\mathrm{CH}_{2}\right)_{2} \mathrm{Ph} \\
& \mathrm{R}^{1}=\mathrm{CH}_{2} \mathrm{CO}_{2} \mathrm{Et}_{1} \mathrm{CH}_{3}, \mathrm{H} \\
& \text { * Mixture of isomers when } \mathrm{EWG}=\mathrm{CN}
\end{aligned}
$$

\section{Scheme 1}

\section{Results and Discussion}

The comparative results, regarding the conventional preparation ${ }^{12}$ and $\mathrm{MW}$-assisted syntheses of $\mathbf{4}$, using a focused single-mode microwave reactor (Method A) and domestic microwave unit (Method B), are summarized in Table 1 .

Our investigation began by examining a wide variety of reaction conditions for focused MWmediated reactions of neat nitriles 1 (entries 4-6) with 1.1 molar equivalent of diethyl $\alpha$ mercaptobutandioate in the presence of a catalytic amount of potassium carbonate. Ultimately, we found that upon controlled irradiation of the reaction mixture at $80{ }^{\circ} \mathrm{C}$ and $150 \mathrm{~W}$ (Method A) almost complete consumption of the reactants was indicated after 2 minutes (TLC). Yields of isolated, chromatographically purified products 4d-f were quite good (69-95\%) and better than 
these of the conventional method. Moreover, preliminary reactions (entries 8 and 9) carried out in the unmodified domestic oven, applying 50\% of the max. power of $750 \mathrm{~W}$ (Method B), afforded, after only 10 seconds, the desired 4-oxothiazolidines $\mathbf{4 h}$ and $\mathbf{4 i}$ in high yields, practically without side products.

Table 1. Synthesis of 4-oxothiazolidines 4 by conventional method and under MW irradiation

\begin{tabular}{|c|c|c|c|c|c|c|}
\hline \multirow[b]{2}{*}{ Entry } & \multirow[b]{2}{*}{ Products } & \multirow[b]{2}{*}{ EWG } & \multirow[b]{2}{*}{$\mathrm{R}^{1}$} & \multicolumn{3}{|c|}{ Yield $(\%)^{\mathrm{a}}$} \\
\hline & & & & $\begin{array}{c}\text { Conventional } \\
\text { Method }^{\mathrm{b}}\end{array}$ & $\begin{array}{c}\text { MW } \\
\text { Method } \mathbf{A}^{\mathrm{c}}\end{array}$ & $\begin{array}{c}\text { MW } \\
\text { Method } \mathbf{B}^{\mathrm{d}}\end{array}$ \\
\hline 1 & $4 \mathbf{a}$ & $\mathrm{COPh}$ & $\mathrm{CH}_{2} \mathrm{CO}_{2} \mathrm{Et}$ & 68 & 59 & 65 \\
\hline 2 & $4 b$ & $\mathrm{COPh}$ & $\mathrm{H}$ & 79 & 20 & 51 \\
\hline 3 & $4 c$ & $\mathrm{COPh}$ & $\mathrm{CH}_{3}$ & 63 & 10 & 10 \\
\hline 4 & $4 d$ & $\mathrm{CO}_{2} \mathrm{Et}$ & $\mathrm{CH}_{2} \mathrm{CO}_{2} \mathrm{Et}$ & 62 & 86 & 72 \\
\hline 5 & $4 e$ & $\mathrm{CO}_{2} \mathrm{Et}$ & $\mathrm{H}$ & 67 & 95 & 54 \\
\hline 6 & $4 f$ & $\mathrm{CO}_{2} \mathrm{Et}$ & $\mathrm{CH}_{3}$ & 59 & 69 & 87 \\
\hline 7 & $4 g$ & $\mathrm{CN}$ & $\mathrm{CH}_{2} \mathrm{CO}_{2} \mathrm{Et}$ & 68 & 88 & 87 \\
\hline 8 & $4 h$ & $\mathrm{CN}$ & $\mathrm{H}$ & 68 & 88 & 83 \\
\hline 9 & $4 \mathbf{i}$ & $\mathrm{CN}$ & $\mathrm{CH}_{3}$ & 75 & 78 & 99 \\
\hline 10 & $4 j$ & CONHPh & $\mathrm{CH}_{2} \mathrm{CO}_{2} \mathrm{Et}$ & 77 & 49 & 39 \\
\hline 11 & $4 k$ & CONHPh & $\mathrm{H}$ & 97 & 66 & 92 \\
\hline 12 & 41 & $\mathrm{CONH}\left(\mathrm{CH}_{2}\right)_{2} \mathrm{Ph}$ & $\mathrm{CH}_{2} \mathrm{CO}_{2} \mathrm{Et}$ & 60 & 63 & 88 \\
\hline 13 & $4 m$ & $\mathrm{CONH}\left(\mathrm{CH}_{2}\right)_{2} \mathrm{Ph}$ & $\mathrm{H}$ & 83 & 86 & 55 \\
\hline 14 & $4 n$ & $\mathrm{CONH}\left(\mathrm{CH}_{2}\right)_{2} \mathrm{Ph}$ & $\mathrm{CH}_{3}$ & 80 & 66 & 81 \\
\hline
\end{tabular}

a Products purified by chromatography; the spectroscopic data of compounds $\mathbf{4 a - b}$ and $\mathbf{4 d - l}$ were identical with these of the authentic samples prepared previously by conventional method. ${ }^{12}$

${ }^{\mathrm{b}} \mathrm{Rxn}$. time: $2-9 \mathrm{~h}$; molar ratio $\mathbf{1} / \mathbf{2}=1 / 1$ to $1 / 1.7$; solvent: EtOH; catalyst: $\mathrm{K}_{2} \mathrm{CO}_{3}$.

${ }^{\mathrm{c}}$ Method A: Single mode MW irradiation at $80{ }^{\circ} \mathrm{C}$ and $150 \mathrm{~W}$ power for 2 min.; molar ratio $\mathbf{1} / \mathbf{2}=1 / 1.1$.

d Method B: MW irradiation applying 50-100\% of the maximum power $(750 \mathrm{~W})$, for $10-150$ seconds; in some cases sequential irradiations (30 seconds each) were applied for the total time (150 seconds).

The multiple rate enhancement reflects obviously the faster heating of the reaction mixture due to the increased microwave power. However, in terms of the polar mechanism, depicted in Scheme 1, the stereoselective synthesis of (Z)-4-oxothiazolidine derivatives 4 is thought to be a perfect case for the observation of the specific MW effect. ${ }^{1}$ Namely, based on our calculations using the MNDO-PM3 method, it has been established that in the conventional synthesis of $(Z)-4$ oxothiazolidine derivatives 4 the ring-formation (step $3 \rightarrow \mathbf{4}$ ) occurs via the anionic intermediate 3 . ${ }^{14}$ As a consequence, the polarity of the system increases during the reaction course from reactants 1 
and $\mathbf{2}$ to the more stabilized transition state, that structurally resembles the anionic species $\mathbf{3}$. Therefore, an expected decrease in the activation energy of the MW-initiated reactions, correlates with the strong rate acceleration. The two-step one-pot reaction (Scheme 1), proceeded under precise temperature and power settings with a diverse range of reactants $\mathbf{1}$ and $\mathbf{2}$, indicating the generality of the method $\mathbf{A}$. In the case of 4-oxothiazolidines $\mathbf{4 j - n}$, reactions took place at the temperature well below the melting points of the starting nitriles $1 .{ }^{12,15}$ Synthesis of compounds 4 in the house microwave oven occurred with equal facility (Table 1; last column). All of the above examples, unlike the classical method, refer to the solvent-free synthesis of 4-oxothiazolidines $4^{16}$ without solid support. In contrast to the accelerated MW synthesis, the conventional one, which does not proceed without solvent, requires, under the optimized conditions, drastically longer reaction times $(2-9 \mathrm{~h})$ and the use of a larger molar excess of the mercapto reactant 2 relative to nitrile 1 (Table 1, column V). As can be seen graphically in Figure 1, only MW-assisted reaction of $1(\mathrm{EWG}=\mathrm{COPh})$ and $\mathbf{2}\left(\mathrm{R}^{2}=\mathrm{CH}_{3}\right)$ did not effectively proceed under the usual reaction conditions, $4 \mathbf{c}$ being formed in low $10 \%$ yield. In both cases, in addition to the products $\mathbf{4 b}$ and $\mathbf{4 c}$, the corresponding reactants were recovered. Interestingly, the cyclized product $\mathbf{4 b}$ was produced in a satisfactory yield (50\%) using the domestic MW unit (Method B), but under the focused irradiation (Method A) the yield was only $20 \%$.

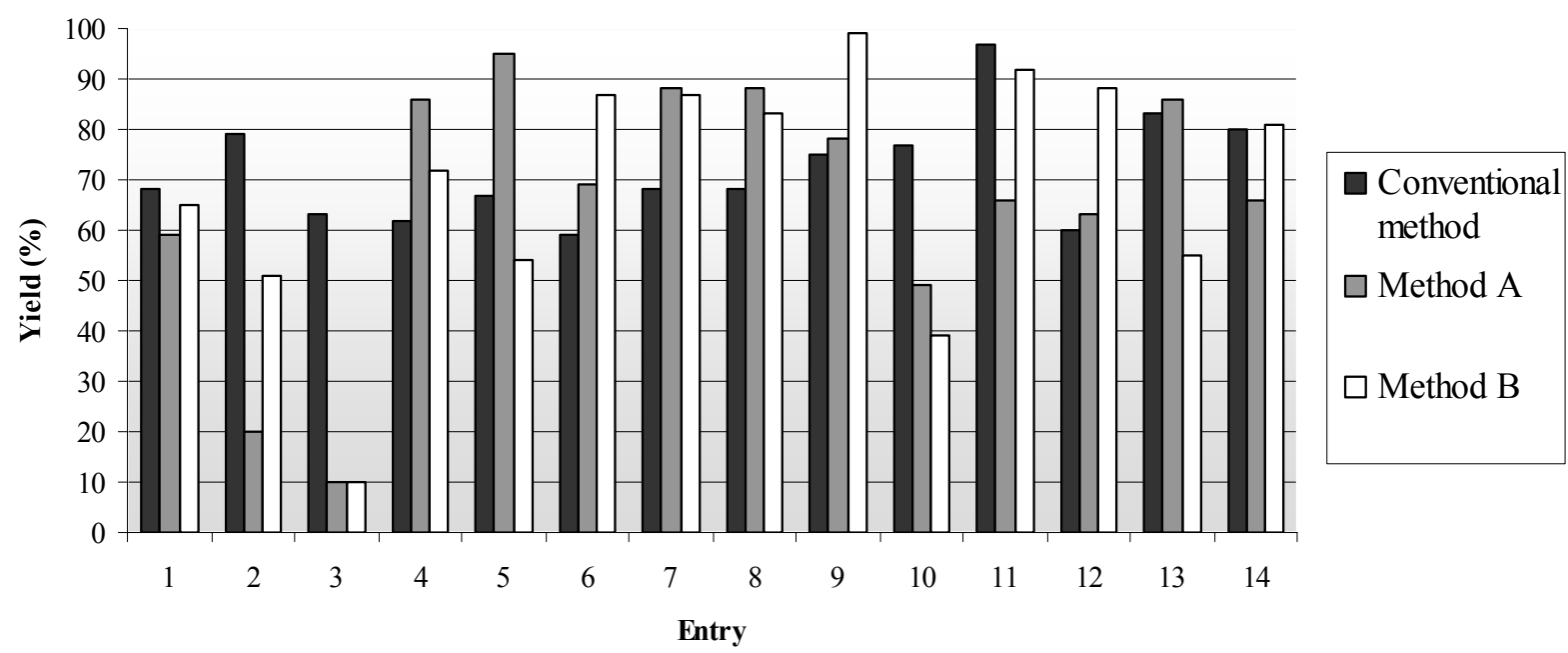

Figure 1. Yield comparison of 4-oxothiazolidines 4 by conventional procedure and MW methods $\mathbf{A}$ and $\mathbf{B}$.

In all conventional syntheses, as established in earlier studies, ${ }^{12}$ and in syntheses under the influence of microwaves as well, the products 4 were isolated as the single ( $Z$ )-isomers. An exception refers to the $Z, E$-mixtures in the case of 4-oxothiazolidines 4, containing the nitrile group attached to the exocyclic $\mathrm{C}=\mathrm{C}$ bond (entries 7-9). In addition, the heterocyclization step, occurring through in situ formed intermediate 3 (with $\mathrm{EWG}=\mathrm{CH}_{2} \mathrm{CO}_{2} \mathrm{Et}$ ), proceeded in a regiospecific manner to give only 2-alkylidene-4-oxothiazolidines. An alternative mode of intramolecular 
cyclization, leading to the concurrent six-membered ring 4-oxo-1,3-thiazinane derivatives, was not observed.

Noteworthy in this context is the possibility to carry out time-controlled microwave synthesis of thiazinane-type products $\mathbf{6}^{11}$ with the $\beta$-mercapto-substituted substrates and nitriles 1 (Scheme 2). For instance, when malononitrile was reacted with an equimolar amount of 3-mercaptopropanoate with $5 \mathrm{~mol} \%$ of $\mathrm{K}_{2} \mathrm{CO}_{3}$ as a catalyst in ethanol, under focused microwave irradiation for 10 minutes, the corresponding 2-(4-oxo-1,3-thiazinan-2-ylidene)acetonitrile (6; EWG = CN) was obtained in $27 \%$ yield. In sharp contrast, the reaction of 5 with ethyl cyanoacetate under the thermal heating in ethanol solution led to a complex mixture, whereas the expected product 6 (EWG = $\left.\mathrm{CO}_{2} \mathrm{Et}\right)$ was isolated in negligible yield $(3 \%)$.



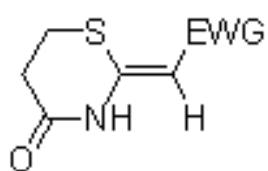

(Z) $-6(27 \%)$
Rxn. conditions

Molar ratio $\mathbf{1 / 5}=1 / 1$

$150 \mathrm{~W}$

$\mathrm{N}_{2}$ cooling, 3 bar

$\mathrm{EtOH}, 10 \mathrm{~min}, 73^{\circ} \mathrm{C}$

Molar ratio $1 / 5=1 / 6$

$150 \mathrm{~W}$

$\mathrm{EtOH}, 2 \min , 88^{\circ} \mathrm{C}$

\section{Scheme 2}

Furthermore, shorter microwave exposure of the same reaction mixture ( 2 minutes), in the presence of the large excess of the reactant 5 (Scheme 2), yielded in moderate yield the addition product, ethyl 3-amino-3-(2-ethoxycarbonylethylsulfanyl)propenoate (7), that is the intermediate leading to ethyl (4-oxo-1,3-thiazinan-2-ylidene)ethanoate (6; $\mathrm{EWG}=\mathrm{CO}_{2} \mathrm{Et}$ ). Under the reaction conditions employed, the heterocycle 6 was not detected even in minute quantities. The lack of cyclization of 7 into the cyclic compound $\mathbf{6}$ can be adequately explained by taking into account the stability of 7 due to the formation of intramolecular hydrogen bond between the proximal amino and ester groups. However, the isolation of 7 under these reaction conditions is another comparative advantage of the microwave-controlled reaction. This indicates that MW procedure could be adaptable to a wide range of similar processes giving rise to heterocyclic compounds of synthetic and biological interest.

In summary, we have demonstrated the feasibility of regio- and stereoselective MW-induced synthesis of a series of (Z)-2-alkylidene-4-oxothiazolidines from activated $\beta$-oxonitriles $\mathbf{1}$ and $\alpha$ mercaptoesters 2 . In comparison to classical synthesis, the method is simpler, faster and environmentally cleaner, as no organic solvent andor solid support have been employed during the reaction course. 


\section{Experimental Section}

General Procedures. Typical experimental procedure for the reactions carried out in a CEM Focused Microwave Synthesizer (Method A): thoroughly mixed neat nitrile 1 (1 mmol), mercapto reactant $2(1.1 \mathrm{mmol})$ and potassium carbonate $(2 \%$ mol equivalent $)$ were placed in a glass vial containing a small stirring bar. The glass vial was sealed and exposed to microwaves $(150 \mathrm{~W})$ at 80 $\mathrm{C}^{\circ}$ for 2 minutes. After cooling to room temperature, the progress of the reaction was checked by TLC. In two cases during the unsatisfactory synthesis of $\mathbf{4 b}$ and $\mathbf{4 c}$, as indicated by the presence of appreciable amounts of reactants, the reaction mixture was irradiated again for another $2 \mathrm{~min}$, however without result in terms of better yields. In all other cases the reaction mixture was dissolved in an appropriate solvent (ethyl acetate, ethanol or acetonitrile) filtered and concentrated to a small volume. The resulting viscous residue or suspension was chromatographed on silica (toluene/ethyl acetate gradient) affording the final product $\mathbf{4}$ as white crystals. As in the case of 2alkylidene-4-oxothiazolidines $\mathbf{4 a - b}$ and $\mathbf{4 d - 1}$, previously synthesized by conventional method, ${ }^{12}$ the structural assignments of new compounds $4 \mathbf{c}, \mathbf{4 m}$ and $\mathbf{4 n}$ were made on the basis of spectroscopic data (IR, ${ }^{1} \mathrm{H}$ and ${ }^{13} \mathrm{C}$ NMR, MS, UV) and elemental analysis. Analytically pure samples were obtained by crystallization from ethanol.

(Z)-(5-Methyl-4-oxothiazolidin-2-ylidene)-1-phenylethanone (4c). Mp 209-211 ${ }^{\circ} \mathrm{C}$; IR $\left(\mathrm{CHCl}_{3}\right.$, $\mathrm{cm}^{-1}$ ) 3254, 3082, 1708, 1627, 1598, 1576, 1522, 1453, 1370, 1309, 1250, 1181, 813, 780, 748 and 698; ${ }^{1} \mathrm{H}-\mathrm{NMR}\left(200 \mathrm{MHz}\right.$; DMSO-d 6 ) 1.50 (3 H d, J 7.2, $\mathrm{CH}_{3}$ ), 4.08 (1 H, q, J 7.2, CHS), $6.80(1 \mathrm{H}$, $\mathrm{s},=\mathrm{CH}), 7.48-7.63(3 \mathrm{H}, \mathrm{m}, \mathrm{m}$ - and p-phenyl), 7.83-7.87 (2 H, m, o-phenyl), $11.80(1 \mathrm{H}, \mathrm{s}, \mathrm{NH})$; ${ }^{13} \mathrm{C}-\mathrm{NMR}\left(50 \mathrm{MHz}\right.$; DMSO-d 6 ) 18.3 $\left(\mathrm{CH}_{3}\right), 41.0(\mathrm{CHS}), 94.5(=\mathrm{CH}), 127.3$ (o-phenyl), $129.0(\mathrm{~m}$ phenyl), 132.3 (p-phenyl), 138.5 (C1-phenyl), $160.6(\mathrm{C}=), 177.7\left(\mathrm{CO}_{\text {ring }}\right), 187.5$ ( $\left.\mathrm{CO}_{\text {ketone }}\right) ; \mathrm{MS} \mathrm{m} / \mathrm{z}$ : $234(\mathrm{M}+1)$; UV $\lambda_{\max }(\mathrm{DMSO}) / \mathrm{nm} 335\left(\varepsilon / \mathrm{dm}^{3} \mathrm{~mol}^{-1} \mathrm{~cm}^{-1} 23300\right)$; Anal. Calc. for $\mathrm{C}_{12} \mathrm{H}_{11} \mathrm{NO}_{2} \mathrm{~S}: \mathrm{C}$, 61.78 ; H, 4.75; N, 6.00; S, 13.75\%; Found: C, 61.60; H, 4.70; N, 6.03; S, 13.97\%.

(Z)-(4-Oxothiazolidin-2-ylidene)- $\mathrm{N}$-(2-phenylethyl)ethanamide $\quad$ (4m). Mp 205-206 ${ }^{\circ} \mathrm{C}$; IR $\left(\mathrm{CHCl}_{3}, \mathrm{~cm}^{-1}\right)$ 3312, 3166, 3055, 1699, 1640, 1565, 1497, 1463, 1311, 1267, 1184, 886, 818, 787, 729 and 692; ${ }^{1} \mathrm{H}-\mathrm{NMR}\left(200 \mathrm{MHz}\right.$; DMSO-d $\left.d_{6}\right) 2.71\left(2 \mathrm{H}, \mathrm{t}, J\right.$ 7.3, $\left.\mathrm{CH}_{2} \mathrm{Ph}\right), 3.25-3.35(2 \mathrm{H}, \mathrm{m}$, $\left.\mathrm{NCH}_{2}\right), 3.63\left(2 \mathrm{H}, \mathrm{s}, \mathrm{CH}_{2} \mathrm{~S}\right), 5.59(1 \mathrm{H}, \mathrm{s},=\mathrm{CH}), 7.15-7.33(5 \mathrm{H}, \mathrm{m}, \mathrm{Ph}), 7.83(1 \mathrm{H}, \mathrm{t}, J$ 5.4, $\left.\mathrm{NH}_{\text {amide }}\right), 11.27\left(1 \mathrm{H}, \mathrm{s}, \mathrm{NH}_{\text {ring }}\right) ;{ }^{13} \mathrm{C}-\mathrm{NMR}\left(50 \mathrm{MHz}\right.$; DMSO-d $\left.d_{6}\right) 32.1\left(\mathrm{CH}_{2} \mathrm{~S}\right), 35.7\left(\mathrm{CH}_{2} \mathrm{Ph}\right), 40.3$ $\left(\mathrm{NCH}_{2}\right), 92.7(=\mathrm{CH}), 126.3$ (p-phenyl), 128.6 (o-phenyl), 128.9 (m-phenyl), 139.9 (C1-phenyl), $151.9(\mathrm{C}=), 166.8\left(\mathrm{CO}_{\text {amide }}\right), 174.3\left(\mathrm{CO}_{\text {ring }}\right)$; MS m/z: $263(\mathrm{M}+1)$; UV $\lambda_{\max }(\mathrm{DMSO}) / \mathrm{nm} 283\left(\varepsilon / \mathrm{dm}^{3}\right.$ $\mathrm{mol}^{-1} \mathrm{~cm}^{-1} 23$ 150); Anal. Calc. for $\mathrm{C}_{13} \mathrm{H}_{14} \mathrm{~N}_{2} \mathrm{O}_{2} \mathrm{~S}$ : C, 59.52; H, 5.38; N, 10.68; S, 12.22\%; Found: C, 59.47; H, 5.38; N, 10.61; S, 12.51\%.

(Z)-(5-Methyl-4-oxothiazolidin-2-ylidene)-N-(2-phenylethyl)ethanamide (4n). Mp $195{ }^{\circ} \mathrm{C}$; IR $\left(\mathrm{CHCl}_{3}, \mathrm{~cm}^{-1}\right) 3295,3084,3054,1702,1644,1576,1499,1456,1374,1314,1275,1184,823,786$, 735 and 699; ${ }^{1} \mathrm{H}-\mathrm{NMR}\left(200 \mathrm{MHz}\right.$; DMSO- $\left.d_{6}\right) 1.41\left(3 \mathrm{H}, \mathrm{d}, J\right.$ 7.2, $\left.\mathrm{CH}_{3}\right), 2.71\left(2 \mathrm{H}, \mathrm{t}, J\right.$ 7.3, $\left.\mathrm{CH}_{2} \mathrm{Ph}\right)$, 3.24-3.35 (2 H, m, $\left.\mathrm{CH}_{2} \mathrm{~N}\right), 3.89(1 \mathrm{H}, \mathrm{q}, J$ 7.2, CHS $), 5.57(1 \mathrm{H}, \mathrm{s},=\mathrm{CH}), 7.16-7.33(5 \mathrm{H}, \mathrm{m}, \mathrm{Ph})$, $7.84\left(1 \mathrm{H}, \mathrm{t}, J\right.$ 5.4, $\left.\left.\mathrm{NH}_{\text {amide }}\right), 11.23\left(1 \mathrm{H}, \mathrm{br} \mathrm{s}, \mathrm{NH}_{\text {ring }}\right) ;{ }^{13} \mathrm{C}-\mathrm{NMR}(50 \mathrm{MHz} \text {; DMSO-d })_{6}\right) 19.0\left(\mathrm{CH}_{3}\right)$, 
$35.6\left(\mathrm{CH}_{2} \mathrm{Ph}\right), 40.3\left(\mathrm{NCH}_{2}\right), 40.6(\mathrm{CHS}), 92.7$ (=CH), 126.2 (p-phenyl), 128.5 (o-phenyl), 128.8 ( $\mathrm{m}$ phenyl), 139.9 (C1-phenyl), $150.0(\mathrm{C}=), 166.6$ ( $\left.\mathrm{CO}_{\text {amide }}\right), 176.9\left(\mathrm{CO}_{\text {ring }}\right)$; MS m/z: $277(\mathrm{M}+1)$; UV $\lambda_{\max }(\mathrm{DMSO}) / \mathrm{nm} 284\left(\varepsilon / \mathrm{dm}^{3} \mathrm{~mol}^{-1} \mathrm{~cm}^{-1} 27\right.$ 200); Anal. Calc. for $\mathrm{C}_{14} \mathrm{H}_{16} \mathrm{~N}_{2} \mathrm{O}_{2} \mathrm{~S}$ : C, 60.85; H, 5.84; N, 10.14; S, 11.60\%; Found: C, 60.54; H, 5.83; N, 10.11; S, 11.69\%.

\section{Acknowledgements}

Financial support from the Ministry of the Republic of Serbia, grant no. 1709 (to R.M.) is acknowledged here.

\section{References}

1. (a) Perreux, L.; Loupy A. Tetrahedron 2001, 57, 9199. (b) Lindström, P.; Tierney, J.; Wathey, B.; Westman, J. Tetrahedron 2001, 57, 9225. (c) Loupy, A.; Petit, A.; Hamelin, J.; TexierBoullet, F.; Jacquault, P.; Mathe, D. Synthesis 1998, 1213.

2. Xu, Y.; Guo, Q.-X.; Heterocycles 2004, 63, 903.

3. (a) Gududuru, V.; Nguyen, V.; Dalton, J. T.; Miller, D. D. Synlett 2004, 2357. (b) Rao, A.; Chimirri, A.; Ferro, S.; Monforte, A. M.; Monforte, P.; Zappalà, M. Arkivoc 2004, 147. (c) Kidwai, M.; Negi N.; Misra, P. J. Indian Chem. Soc. 2000, 77, 46; (d) Chandrasekhar, S.; Padmaja, M. B.; Raza, A. Synlett 1999, 1597. (e) Fraga-Dubreuil, J.; Bazureau, J. P. Tetrahedron 2003, 59, 6121.

4. Singh, S. P.; Parmar, S. S.; Raman, K.; Stenberg, V. I. Chem. Rev. 1981, 81, 175.

5. Nagase, H. Chem. Pharm. Bull. 1973, 21, 270.

6. Roggero J.; Audibert, M. Bull. Soc. Chim. Fr. 1971, 4021.

7. Albrecht U.; Langer, P. Synlett 2004, 1963.

8. (a) Marković, R.; Baranac, M.; Stojanović, M. Synlett 2004, 1034. (b) Marković, R.; Shirazi, A.; Džambaski, Z.; Baranac, M.; Minić, D. J. Phys. Org. Chem. 2004, 17, 118. (c) Marković, R.; Baranac, M.; Jovetić, S. Tetrahedron Lett. 2003, 44, 7087. (d) Marković, R.; Baranac, M.; Džambaski, Z. Heterocycles 2004, 63, 851.

9. Hoshino, Y.; Mukai, A.; Yazawa, K.; Uno, J.; Ishikawa, J.; Ando, A.; Fukai, T.; Mikami, Y. J. Antibiot. 2004, 57, 797.

10. Kucukguzel, S. G.; Oruc, E. E.; Rollas, S.; Sahin, F.; Ozbek, A. Eur. J. Med. Chem. 2002, 37, 197.

11. Satzinger, G. Liebigs Ann. Chem. 1978, 473.

12. Marković, R.; Baranac, M.; Džambaski, Z.; Stojanović, M.; Steel, P. J. Tetrahedron 2003, 59, 7803.

13. Kerneur, G.; Lerestif, J. M.; Bazureau, J. P.; Hamelin, J. Synthesis 1997, 287.

14. Marković, R.; Vitnik, Ž.; Baranac, M.; Juranić, I. J. Chem. Research (S) 2002, 485.

15. Ješelnik, M.; Varma, R. S.; Polanc, S.; Kočevar, M. Green Chem. 2002, 4, 35. 
16. (a) Tanaka, K.; Toda, F. Chem. Rev. 2000, 100, 1025. (b) Filippi, J. J.; Fernandez, X.; LizzaniCuvelier, L.; Loiseau, A. M. Tetrahedron Lett. 2003, 44, 6647. (c) Perin, G.; Jacob, R. G.; de Azambuja, F.; Botteselle, G. V.; Siqueira, G. M.; Freitag, R. A.; Lenardão, E. J. Tetrahedron Lett. 2005, 46, 1679. (d) Kodomari, M.; Tamaru Y.; Aoyama, T. Synth. Commun. 2004, 34, 3029. 